\title{
DIRASAH
}

Volume 3, Number 1, Februari 2020

p-ISSN: 2615-0212 | e-ISSN: 2621-2838

https://ejournal.iaifa.ac.id/index.php/dirasah

\begin{tabular}{|c|c|c|}
\hline Accepted: & Revised: & Published: \\
Januari 2020 & Januari 2020 & Februari 2020 \\
\hline
\end{tabular}

\section{Implementasi Strategi Pemasaran Pendidikan di Madrasah}

\author{
Dian \\ UIN Sunan Gunung Djati Bandung, Indonesia \\ e-mail:dian@uisgd.ac.ad \\ Ilis Rosbiah \\ UIN Sunan Gunung Djati Bandung, Indonesia \\ e-mail:irosbiah@gmail.com

\section{Ari Prayoga} \\ Perkumpulan Sarjana Manajemen Pendidikan Islam (PERSMAPI) Indonesia \\ e-mail: ariprayoga@madrasah.id
}

\begin{abstract}
Competition between educational institutions, especially the private sector in order to get new students is very tight, this can be seen by the many educational institutions that implement marketing strategies to attract as many students as possible. This study aims to reveal the implementation of educational services marketing strategies with the foundation of management theory and marketing mix in Madrasah Aliyah Miftahurroja Lebakmuncang-Ciwidey, Indonesia. The method used in this research is descriptive with a qualitative approach. Collecting data in this study are, observations of the internal and external environment of madrasas, interviews with madrasah heads, deputy heads of curriculum, educators, committee and pamphlet study documents, list of institutions, madrasah marketing agenda. Data analysis techniques used are to do data reduction, data presentation and drawing conclusions. The results of this study indicate that: first, the marketing strategy of education services to improve the quality of education in MA Miftahurroja Lebakmuncang Ciwidey by using the management function, there are four stages, namely Planning, organizing, implementing and evaluating. Secondly, the implementation of an education services marketing strategy in MA Miftahurroja Lebakmuncang through marketing mix namely; products, places, prices, promotions, people,
\end{abstract}


physical evidence, and processes. The competitiveness of MA Miftahurroja Lebakmuncang Ciwidey is good enough, it can be seen from the data of the increasing number of students.

Keywords: Strategy, Marketing, Education Services.

\begin{abstract}
Abstraksi
Persaingan antara lembaga pendidikan, terutama sektor swasta dalam rangka untuk mendapatkan siswa baru sangat ketat, hal ini dapat dilihat dari banyaknya lembaga pendidikan yang menerapkan strategi pemasaran untuk menarik siswa sebanyak mungkin. Penelitian ini bertujuan untuk mengungkap pelaksanaan strategi pemasaran jasa pendidikanberdasarkan teori manajemen dan bauran pemasaran di Madrasah Aliyah Miftahurroja LebakmuncangCiwidey, Indonesia. Metode yang digunakan dalam penelitian ini adalah deskriptif dengan pendekatan kualitatif. Pengumpulan data dalam kajian ini adalah dengan pengamatan lingkungan internal dan eksternal madrasah, wawancara dengan kepala madrasah, wakil kepala madrasah bidang kurikulum, pendidik, komite dan dokumentasi dari pamflet, daftar lembaga, agenda pemasaran madrasah. Teknik analisis data yang digunakan adalah untuk melakukan pengurangan data, penyajian data dan menarik kesimpulan. Hasil kajian ini menunjukkan bahwa: pertama, strategi pemasaran jasa pendidikan untuk meningkatkan mutu pendidikan di MA Miftahurroja Lebakmuncang Ciwidey dengan menggunakan fungsi manajemen, ada empat tahapan, yaitu perencanaan, pengorganisasian, pelaksanaan dan evaluasi. Kedua, pelaksanaan strategi pemasaran jasa pendidikan di MA Miftahurroja Lebakmuncang melalui marketing mix yaitu; produk, tempat, harga, promosi, orang, bukti fisik, dan proses. Daya saing MA Miftahurroja Lebakmuncang Ciwidey cukup baik ha itu dapat dilihat dari data peningkatan jumlah siswa.
\end{abstract}

Kata kunci: strategi, pemasaran, layanan pendidikan.

\title{
Pendahuluan
}

Dewasa ini perkembangan ilmu pengetahuan dan teknologi telah menuntut masyarakat untuk melakukan perubahan di berbagai bidang, tidak terkecuali dalam bidang pendidikan. Persaingan yang ketat antar lembaga pendidikan saat ini bukan suatu rahasia lagi, hal ini tentunya menuntut setiap lembaga pendidikan untuk dapat menggali keunikan dan keunggulan dan kemudian dijadikan modal dalam memasarkan lembaganya itu. Pemasaran jasa pendidikan dahulu dianggap tabu karena berbau bisnis dan cenderung Dirasah, Vol. 3, No. 1, Februari 2020 
berorientasi pada laba (profit oriented), namun sekarang aktivitas ini sudah banyak dilakukan secara terbuka dan terang terangan ${ }^{1}$.

Pemasaran jasa pendidikan merupakan strategi untuk meningkatkan mutu lembaga pendidikan, bukan hanya dilihat dari segi pembelajaran yang berkualitas, sarana prasarana dan sumber daya manusia yang berkualitas saja, melainkan keseluruhan warga lembaga pendidikan itu untuk saling berpadu memberikan pelayanan semaksimal mungkin terhadap pelanggan. Pelanggan adalah siswa yang telah menjadi pelanggan ataupun calon siswa dari masyarakat luas yang akan menjadi pelanggan lembaga pendidikan².

Salah satu lembaga pendidikan yang menjadi pilihan alternatif masyarakat adalah madrasah. Madrasah dipercaya oleh masyarakat sebagai lembaga pendidikan yang tidak hanya dapat mengembangkan pendidikan formal melainkan pendidikan agamanya juga. Kemampuan berkompetisi menentukan madrasah itu mampu bertahan atau tidak. Pengelolaan madrasah menjadi sangat penting, dimana pertumbuhan dan perkembangan madrasah dipengaruhi oleh kemampuan administrator dalam melakukan scaning lingkungan eksternal, kompetitor madrasah lain, memperhitungkan kompetensi internal, harus menciptakan strategi yang mumpuni untuk memenangkan persaingan tanpa meninggalkan esensi dari pendidikan itu sendiri. Pengelolaan madrasah yang baik akan menentukan keberlangsungan dan perkembangan madrasah itu dimasa yang akan datang ${ }^{3}$.

Madrasah harus terus berinovasi melakukan strategi pemasaran jasa pendidikan untuk meningkatkan kualitas dan kuantitasnya. Namun dalam realitanya, terdapat madrasah yang masih berfokus pada pemasaran jangka pendek dan menggunakan pendekatan tradisional sehingga berakhir tidak baik, seperti dibekukannya lembaga pendidikan tersebut dan bangkrut atau ditutup karena kurangnya peminat atau peserta didik. Masalah-masalah lain pun banyak yang bermunculan seperti: keterbatasan anggaran yang dimiliki madrasah, keterbatasan sumber daya manusia, peran kepemimpinan madrasah yang kurang efektif, pengelolaan madrasah yang belum sesuai dengan standar, serta

${ }^{1}$ Maskub Abrori, Strategi Pemasaran Dan Implementasinya Dalam Lembaga Pendidikan, 2nd edn (Bandung: Alfabeta, 2013).

${ }^{2}$ Derizka Inva Jaswita, 'Strategi Pemasaran Jasa Pendidikan Dalam Meningkatkan Volume Penerimaan Siswa Baru SD Kartini Komplek Angkasa Pura II', Jurnal Pemasaran Kompetitif, 2.1 (2018).

3 Tim Dosen Administrasi Pendidikan UPI, Manajemen Pendidikan, Alfabeta, 1st edn (Bandung: Alfabeta, 2011). 
pemasaran yang dianggap tidak penting oleh madrasah, dan ketidakmampuan madrasah untuk menarik animo masyarakat sehingga tidak dapat bersaing dengan sekolah pesaingnya.

Sehubungan dengan beberapa masalah yang ada diatas, MA Miftahurroja Lebakmuncang Ciwidey menjadi salah satu madrasah yang masih memiliki keterbatasan dalam pengelolaan menghadapi tantangan yang semakin ketat, sejalan dengan perubahan masyarakat yang semakin cepat dimana makin maraknya persaingan antar madrasah. Terlebih dengan semakin banyaknya madrasah yang memiliki sistem pendidikan yang serupa, jika tidak diimbangi dengan strategi pemasaran jasa pendidikan yang matang, pengembangan kualitas yang semakin baik, dan juga pelayanan yang memuaskan, maka lambat laun akan tertinggal dengan madrasah baru yang menawarkan berbagai kelebihan.

Dalam hal ini, MA Miftahurroja Lebakmuncang Ciwidey belum memiliki tim pemasaran jasa pendidikan yang dibentuk secara permanen/tetap, selama ini MA Miftahurroja Lebakmuncang Ciwidey hanya membentuk tim khusus pemasaran yang dibentuk pada semester genap saja dengan kurun waktu enam bulan dengan beranggotakan guru dan dibantu dengan organisasi intra sekolah (OSIS) yang ada dimadrasah, sehingga pembagian tugas maupun penanggung jawab dalam merencanakan bahkan melaksanakan pemasaran jasa tidak terlaksana dengan maksimal. Masalah lain yang muncul adalah madrasah belum memiliki anggaran yang cukup untuk kebutuhan pelaksanaan program pemasaran. Biaya yang dianggarkan oleh sekolah sangat minim sehingga cukup sulit bagi stake holder dalam mengembangkan program pemasaran. Hal ini tentu menjadi suatu masalah yang harus diperhatikan oleh pihak madrasah, maka pihak madrasah harus mampu memahami kelebihan dan kelemahan yang dimiliki sebagai bentuk upaya peningkatan daya saing.

\section{Metode Penelitian}

Jenis penelitian ini adalah penelitian kualitatif, yaitu penelitian yang menghasilkan data deskriptif berupa kata-kata tertulis atau lisan dari orangorang dan pelaku yang diamati, diarahkan pada latar belakang individu secara utuh (holistik) tanpa mengisolasikan individu dan organisasi dalam variabel atau hipotesis, tetapi memandangnya sebagai bagian dari suatu keutuhan ${ }^{4}$.

\footnotetext{
${ }^{4}$ Lexy J. Moleong, Metode Penelitian Kualitatif (Bandung: Remaja Rosdakarya, 2004).
}

Dirasah, Vol. 3, No. 1, Februari 2020 
Teknik pengumpulan data pada penelitian ini menggunakan teknik observasi, wawancara, dan studi dokumentasi ${ }^{5}$. Dalam penelitian ini, sumber data primer dari penelitian ini adalah berasal dari wawancara dengan pihakpihak terkait seperti kepala sekolah dan dewan guru MA Miftahurroja Lebakmuncang Ciwidey. Sedangkan data sekunder ialah sumber yang mendukung serta hubungan penelitian yang dibahas dimana sumber data sekunder dalam penelitian ini di antaranya bersumber dari buku-buku, dokumentasi, dan kepustakaan sumber-sumber lainnya yang mendukung serta berkaitan dengan masalah dalam penelitian tersebut. Selain wawancara, dalam penelitian ini peneliti mengumpulkan data dengan menggunakan kegiatan observasi dan studi dokumentasi yang semua data-data tersebut berasal dari pengamatan secara langsung 6 .

\section{Kajian Teori}

\section{Konsep Strategi Pemasaran}

Menurut KBBI, strategi diartikan sebagai suatu rencana cermat mengenai kegiatan untuk mencapai sasaran khusus ${ }^{7}$. Strategi dipandang sebagai sebuah program yang meliputi tujuan yang ingin dicapai, disertai dengan tindakan atau langkah-langkah khusus untuk mencapai tujuan tersebut sebagai usaha merespon lingkungannya ${ }^{8}$. Sedangkan pemasaran menurut Kotler adalah proses sosial dan manajerial yang dilakukan oleh seseorang atau kelompok untuk memperoleh apa yang mereka inginkan melalui penciptaan, penawaran, dan pertukaran produk-produk yang bernilai dengan yang lainnya ${ }^{9}$.

Strategi pemasaran merupakan rangkaian suatu kegiatan yang terarah untuk mencapai sasaran dan dengan pola berpikiryang inovatif dan kreatif, untuk menghadapi kecenderungan yang terjadi di dalam organisasi maupun di luar organisasi, yang akanberpengaruh terhadap kepentingan maupun masa depan organisasi sendiri ${ }^{10}$.

5 Philip Buckley and Irawan Irawan, 'The Scientific Paradigm of Islamic Education Management: Phenomenology Perspective', Jurnal Pendidikan Islam, 02.01 (2015), 1-29.

${ }^{6}$ Suharsini Arikunto, Prosedur Penelitian Suatu Pendekatan Praktek (Jakarta: Rineka Cipta, 2003).

${ }^{7}$ KBBI, Kamus Besar Bahasa Indonesia (KBBI), 4th edn (Jakarta: Balai Pustaka, 2005).

8 Imam Faizin, 'Strategi Pemasaran Jasa Pendidikan Dalam Meningkatkan Nilai Jual Madrasah', Madaniyah, 7.2 (2017).

${ }^{9}$ I Fahmi, Manajemen Strategis, 1st edn (Bandung: Alfabeta, 2015).

${ }^{10}$ Khoirul Anam, 'Strategi Pemasaran Dan Implementasinya Dalam Lembaga Pendidikan', Ta'allum: Jurnal Pendidikan Islam, 1.2 (2013), 159-70. 
Strategi pemasaran pendidikan adalah sebuah cara, upaya, dan langkahlangkah praktis yang dilakukan oleh pemimpin sekolah atau madrasah dalam memasarkan jasa pendidikan melalui pemberian informasi kepada masyarakat dan penawaran layanan jasa pendidikan serta meyakinkan pengguna jasa pendidikan agar tetap menggunakan layanan jasa pendidikan ${ }^{11}$.

Pada perkembangannya, istilah pemasaran tidak hanya dipakai oleh organisasi atau lembaga profit saja, akan tetapi dipakai pula oleh lembaga non profit. Artinya penggunaan istilah marketing saat ini sudah berkembang di segala sektor kegiatan manusia. Hal ini diungkap oleh Morris sebagaimana dikutip oleh Muhaimin, bahwa dewasa ini tidak ada organisasi baik itu bisnis atau non bisnis yang tidak terlepas dari pemasaran (marketing), organisasi tersebut dapat memilih untuk mengerjakannya demi kebaikan organisasi atau meninggalkannya untuk kemunduran ${ }^{12}$.

\section{Bauran Pemasaran Jasa Pendidikan}

Jasa merupakan seluruh aktivitas ekonomi dengan output selain produk dalam pengertian fisik, dikonsumsi dan diproduksi pada saat bersamaan, memberikan nilai tambah dan secara prinsip tidak berwujud bagi pembeli pertamanya. Kotler dalam Alma Bukhori merumuskan jasa adalah segala aktifitas atau manfaat yang dapat ditawarkan satu pihak kepada pihak lain yang pada dasarnya tidak berwujud, dan tidak menghasilkan kepemilikan apapun ${ }^{13}$.

Kotler dalam Afidatun Khasanah mengartikan jasa sebagai setiap tindakan atau kinerja yang ditawarkan oleh satu pihak pada pihak yang lainnya yang secara prinsip tidak berwujud dan tidak menyebabkan kepindahan kepemilikan. Karakteristik jasa dapat diartikan sebagai berikut ${ }^{14}$ : (a) Tidak berwujud (intangible), sehingga konsumen tidak dapat melihat, mencium, meraba, mendengar dan merasakan sebelum mereka membelinya; (b) tidak terpisahkan (inseparability), yakni jasa tidak dapat dipisahkan dari sumbernya; (c) bervariasi (variability) di mana jasaseringkali berubah-rubah tergantung siapa, kapan dan di mana penyajiannya; (c) mudah musnah (perishability), tidak dapat dijual pada masa yang akan dating; (e) jasa tidak dapat disimpan dan dikonsumsi pada saat dihasilkan; (f) konsumen merupakan bagian internal dari proses produksi jasa; (g) setiap orang atau

11 Ari Prayoga and Jaja Jahari, 'Manajemen Jejaring Kerjasama Pondok Pesantren', $A L$ MA'ARIEF : Jurnal Pendidikan Sosial Dan Budaya, 01.02 (2019), 125-33.

12 Muhaimin, Manajemen Pendidikan, Aplikasinya Dalam Penyusunan Rencana Pengembangan Sekolah/Madrasah, 4th edn (Jakarta: Kencana Preneda Media Group, 2012).

${ }^{13}$ Faizin.

${ }^{14}$ Afidatun Khasanah, 'Pemasaran Jasa Pendidikan Sebagai Strategi Peningkatan Mutu Di SD Alam Baturraden', El Tarbawi, 8.2 (2015), 161-76.

Dirasah, Vol. 3, No. 1, Februari 2020 
apapun yang ikut berhubungan dengan konsumen mempunyai andil dalam memberika peranan; (h) karyawan penghubung merupakan bagian dari proses produksi jasa; (i) Kualitas jasa tidak dapat diperbaiki pada saat proses produksi karena produksi jasa terjadi secara real time.

Dalam pemasaran jasa pendidikan menurut faizin tidak bisa terlepas dari elemen bauran pemasaran. Adapun bauran pemasaran jasa yang dimaksud adalah konsep 7P yaitu ${ }^{15}$ :

a. Product (Produk)

Produk pendidikan merupakan segala sesuatu yang ditawarkan, bertujuan untuk memenuhi kebutuhan dan keinginannya. Dalam lingkungan pendidikan, produk jasa yang dapat ditawarkan adalah jasa layanan akademik seperti kurikulum atau ekstra kurikulum.

b. Price (harga)

Strategi harga yang terjangkau untuk semua kalangan dapat berpengaruh terhadap pemilihan sekolah. Umumnya, orang tua yang berpenghasilan menengah ke bawah, memilih sekolah yang relatif lebih murah, kecuali jika memperoleh beasiswa, sedangkan orang tua yang berpenghasilan menengah ke atas, memilih sekolah terbaik, walaupun dengan biaya yang relatif tidak murah.

c. Place (Lokasi/Tempat)

Lokasi strategis yang mudah dijangkau dari segala arah dengan kendaraan umum maupun kendaraan pribadi, juga kemudahan akses menuju sekolah merupakan faktor pendukung kenyamanan siswa, orang tua dan masyarakat sekitar sekolah.

d. Promotion (Promosi)

Promosi merupakan salah satu faktor penentu keberhasilan program pemasaran. Kegiatan promosi sendiri dapat dilakukan melalui media komunikasi massa misalnya; koran, majalah, televisi, papan reklame, dan gambar tempel. Selain itu promosi juga bisa dilakukan melalui keterlibatan alumni-alumni yang senantiasa ikut mempromosikan kepada masyarakat.

e. Person (Sumber Daya Manusia)

Orang (people) adalah semua pelaku yang memainkan peran dalam penyajian jasa sehingga dapat mempengaruhi persepsi pembeli. Untuk mewujudkan Sumber Daya Manusia (guru) di lingkungan sekolah yang professional, diperlukan sistem rekrutmen yang profesional. Selain guru yang berkualitas dan ramah, karyawan dan administrasi dan non

15 Maskub Abrori, 'Strategi Pemasaran Lembaga Pendidikan Untuk Meningkatkan Jumlah Peserta Didik Di PG/TK Samarinda', SYAMIL: Jurnal Pendidikan Agama Islam (Journal of Islamic Education), 3.2 (2015).

Dirasah, Vol. 3, No. 1, Februari 2020 
administrasi juga diharapkan memiliki kehandalan dan keramahan dalam mengerjakan semua tugas.

\section{f. Physical Evidence (Sarana Fisik)}

Sarana fisik adalah gedung atau bangunan dengan segala sarana dan fasilitas yang ada dalam suatu lembaga pendidikan. Faktor sarana pembelajaran yang memadai merupakan fasilitas yang sangat membantu dalam proses pembelajaran.

g. Process (Proses)

Dalam lembaga pendidikan tentunya menyangkut produk utamanya ialah proses belajar mengajar, dari guru kepada siswa. Apakah kualitas jasa atau pengajaran yang diberikan oleh guru cukup bermutu, atau bagaimana penampilan dan penguasaan bahan. Oleh karena itu, manajemen lembaga pendidikan harus memperhatikan kualitas guru yang sangat menunjang keberhasilan pemasaran dan pemuasan.

\section{Peningkatan Penerimaan Peserta Didik}

Peningkatan adalah proses, cara perbuatan meningkat (usaha kegiatan dan sebagainya) ${ }^{16}$. Adapun yang dimaksud peningkatan adalah proses, cara perbuatan, dan cara perbuatan meningkatkan usaha kegiatan dan sebagainya. Sedangkan penerimaan peserta didik baru adalah salah satu kegiatan manajemen yang sangat penting, karena jika tidak ada peserta didik baru yang diterima di madrasah berarti tidak ada yang harus ditangani atau diatur. Penerimaan siswa baru juga merupakan salah satu kegiatan yang pertama dilakukan yang biasanya dengan mengadakan seleksi calon murid. Jadi yang dimaksud dengan peningkatan penerimaan peserta didik baru adalah usaha yang dilakukan dalam upaya meningkatkan kegiatan mencari dan menentukan calon siswa baru yang biasanya dilakukan menjelang tahun ajaran baru. Strategi Pemasaran Dalam Peningkatan Penerimaan peserta didik baru adalah kegiatan menganalisa, merencanakan, mengimplementasikan, dan mengawasi segala kegiatan (program), guna memperoleh tingkat pertukaran yang menguntungkan dengan pembeli sasaran dalam rangka mencapai tujuan organisasi ${ }^{17}$.

\section{Hasil Penelitian dan Pembahasan}

Strategi pemasaran jasa pendidikan di MA Miftahurroja Lebakmuncang Ciwidey masih dilakukan secara sederhana, namun masih tetap memperhatikan

\footnotetext{
${ }^{16}$ Ari Prayoga and others, 'Implementasi Penjaminan Mutu Madrasah', Muróbbî: Jurnal Ilmu Pendidikan, 3.1 (2019), 70-84.

17 Wakil Kepala Bidang Kurikulum, 'Dokumen Rencana Strategi Madrasah Aliyah Miftahurroja Lebakmuncang Ciwidey’ (Bandung: MAS Miftahurroja, 2019).
}

Dirasah, Vol. 3, No. 1, Februari 2020 
manajemen pemasaran, unsur-unsur strategi pemasaran dan memperkuat bauran pemasaran, yakni melakukan perencanaan, pengorganisasian, pelaksanaan, dan evaluasi. Dari hasil wawancara dengan kepala madrasah menyatakan bahwa MA Miftahurroja Lebakmuncang Ciwidey telah melakukan perumusan unsur strategi dulu sebelum melakukan strategi pemasaran. Sebagai solusi MA Miftahurroja Lebakmuncang Ciwidey telah meluruskan langkah-langkah atau tahapan-tahapan penting dalam strategi pemasaran jasa pendidikan sebagai berikut $^{18}$ :

\section{Perencanaan}

Perencanaan Penyusunan Strategi Pemasaran MA Miftahurroja Lebakmuncang Ciwidey. Langkah awal yang dilakukan oleh MA Miftahurroja Lebakmuncang Ciwidey Perencanaan Penyusunan Strategi Pemasaran, proses penyusun perencanaan ini dilakukan sekitar empat bulan sebelum penerimaan peserta didik baru.

2. Pengorganisasian

Pada tahap ini kepala madrasah menyusun rencana kegiatan, kepanitian dan pelaksanaan penerimaan peserta didik baru. Pertemuan tersebut melibatkan waka kesiswaan, waka sarpras, waka humas, guru BP, kepala-kepala program dan beberapa guru mapel.

3. Pelaksanaan

Pada pelaksanaan target perolehan peserta didik baru, kepala madrasah dan tim panitia bekerja sama dengan kepala sekolah SMP / MTs yang berada di sekitaran madrasah untuk mengarahkan peserta didiknya yang telah lulus untuk melanjutkan ke MA Miftahurroja Lebakmuncang.

\section{Evaluasi}

Evaluasi merupakan langkah terakhir yang dilakukan oleh pihak MA Miftahurroja Lebakmuncang dalam strategi pemasaran. Evaluasi ini dilaksanakan setiap satu tahun sekali, dan melibatkan seluruh stake holder yang berada di MA Miftahurroja Lebakmuncang. Evaluasi ini dilakukan agar program kerja yang telah dibuat tidak keluar dari hal yang telah direncanakan.

\section{Implementasi Bauran Pemasaran Jasa Pendidikan}

Profil MA Miftahurroja Ciwidey

MA Miftahurroja Lebak muncang berlokasi di Jalan CiwideyLebakmuncang KM. 06 Rt. 02 Rw. 05 Desa. Lebakmuncang Kec. Ciwidey Kab. Bandung. Lokasi berdekatan dengan mesjid, sawah, kebun serta perumahan padat penduduk. Visi MA Miftahurroja Lebakmuncang adalah

18 Uus Zaenal, 'Wawancara Bersama Kepala Madrasah MAS Miftahurroja' (Bandung: Researcher, 2019). 
mencetak insan yang berakhlakul karimah berintelektual tinggi, cerdas, tangkas, kreatif, dan inovatif, berguna bagi nusa, bangsa dan agama ${ }^{19}$.

\section{Strategi Bauran Pemasaran}

a. Strategi Produk

Keunggulan sekolah MA Miftahurroja Lebakmuncang Ciwidey dalam hal produk yakni dalam bidang ekstrakurikuler seperti pramuka, paskibra, futsal, dan badminton. Pada di bidang olahraga badminton MA Miftahurroja Lebakmuncang Ciwidey pernah jadi juara 1 aksioma tingkat provinsi.

b. Strategi price

Strategi price yang dilakukan di MA Miftahurroja Lebakmuncang Ciwidey sudah baik. Hal ini dibuktikan dengan semakin meningkatnya jumlah peserta didik yang mendaftar setiap tahunnya. Biaya pendidikan di Miftahurroja Lebakmuncang Ciwidey terjangkau di antaranya uang masuk sebesar 1.000.000,- dan biaya perbulan sebesar 50.000,-. Adapun untuk pembiayaan di MA Miftahurroja Lebakmuncang Ciwidey selain dari para orang tua siswa juga dari Bantuan Opersional Sekolah (BOS) ${ }^{20}$.

c. Strategi Place

Lokasi MA Miftahurroja Lebakmuncang Ciwidey sangat strategis karena lokasinya berada di pinggir jalan. Madrasah ini mempunyai fasilitas area lahan gedung yang lumayan luas dan suasana yang sejuk karena di kelillingi dengan pesawahan. Selain itu juga madrasah ini dilengkapi dengan kolam ikan. Tentunya dengan suasana yang sejuk membuat konsentrasi belajar siswa sangat baik dengan suasana ramah dan nyaman ini siswa akan mudah memahami materi pelajaran yang diberikan kepada mereka. Meskipun berada dipedesaan, namun akses untuk menuju madrasah ini cukup mudah karena jalannya pun sudah cukup baik.

d. Strategi Promotion

Ada dua strategi promosi yang secra umum digunakan oleh pemasar jasa pendidikan yaitu strategi pemasaran below the line dan strategi pemasaran above the line. MA Miftahurroja Lebakmuncang Ciwidey merupakan madrasah yang memasarkan jasa pendidikannya dengan konsep yang pertama, yakni below the line. Sistem pemasaran below the line memasarkan jasa pendidian melalui kegiatan-kegiatan

19 Wakil Kepala Bidang Kurikulum, 'Dokumen 1 Madrasah Aliyah Miftahurroja Lebakmuncang Ciwidey’ (Bandung: MA Miftahurroja, 2019).

${ }^{20}$ Ari Prayoga and Arif Risnandi, 'Manajemen Pembiayaan Pendidikan Di Madrasah Aliyah Darussalam Sumedang', Cakrawala: Jurnal Manajemen Pendidikan Islam Dan Studi Sosial, 03.02 (2019), 117-131.

Dirasah, Vol. 3, No. 1, Februari 2020 
yang mendeskripsikan serta menunjukan prestasi dan kemampuan yang dimiliki oleh madrasah tersebut seperti melalui kegiatan kemasyarakatan, perayaan hari-hari besar Islam, pentas musik di berbagai kegiatan, mengikutsertakan peserta didik ke dalam berbagai perlombaan. Sistem yang diambil oleh MA Miftahurroja Lebakmuncang Ciwidey dalam mempromosikan jasa pendidikan tidak serta merta dirasakan hasilnya seketika, tetapi melalui tahap yang pasti dan juga unjuk kualitas diri. Hal ini karena memang prinsip dari madrsasah ini adalah madrasah yang ingin memiliki kualitas pendidikan yang baik dengan biaya yang relatif terjangkau oleh masyarakat.

e. Stategi People

Pada pelaksanaan kegiatan pendidikan di MA Miftahurroja Lebakmuncang Ciwidey didukung oleh tenaga pendidik dan tenaga kependidikan yang sesuai kompetensi dan kualifikasinya. Hal ini dibuktikan dengan semua tenaga pengajar berpendidikan Strata Satu (S1), ada pula yang berpendidikan Strata Dua (S2). Begitu pula dengan tenaga kependidikan yang mayoritas berpendidikan Strata Satu (S1). Untuk meningkatkan kualitas kompetensi pelayanan pendidikan manajemen, MA Miftahurroja Lebakmuncang Ciwidey selalu mendorong para karyawanya untuk mengikuti kegiatan-kegiatan yang bersifat positif dan menunjang kompetensi, seperti pelatihan, seminar, workshop, dan kegiatan-kegiatan lainnya.

f. Strategi Physical evidence

MA Miftahurroja Lebak muncang Ciwidey cukup menunjang bagi berlangsungnya proses pembelajaran. Adapun keaadaan fakta bukti fisik dimiliki oleh MA Miftahurroja Lebakmuncang Ciwidey adalah kantor kepala madrasah, ruang kelas, ruang guru, ruang tata usaha, perpustakaan, ruang BP, ruang UKS, kantin, koperasi.

g. Strategi Process

Pada aspek kurikulum, MA Miftahurroja Lebakmuncang Ciwidey mengikuti standar yang telah ditetapkan oleh kementerian Pendidikan Nasional. Hal ini dapat terlihat dari muatan mata pelajaran maupun kegiatan yang dilakukan di madrasah ini. Selain itu, kurikulum MA Miftahurroja Lebakmuncang Ciwidey itu sendiri yaitu Kewirausahaan dan Kemandiriaan dimana kedua kurikulum tersebut merupakan ciri khas dari MA Miftahurroja Lebakmuncang Ciwidey. Kegiatan pembelajaran dilakukan secara integrasi dan juga belajar langsung dari muatan belajar praktikum. Pelajaran yang di tanamkan setiap hari dengan adanya kegiatan membaca Al-Quran sebelum memulai pelajaran sehingga peserta didik yang sebelumnya belum lancar membaca Al Quran dengan baik dan benar. Setiap keluhan, 
usulan, dan aspirasi yang disampaikan oleh para wali murid ditampung dengan baik dan dibicarakan secara formal dan bersifat kekeluargaan.

\section{Penutup}

Berdasarkan hasil penelitian tentang strategi pemasaran jasa pendidikan dalam meningkatkan peserta didik baru di MA Miftahurroja Lebakmuncang Ciwidey dapat disimpulkan bahwa; pertama, strategi pemasaran jasa pendidikan di MA Miftahurroja Lebakmuncang Ciwidey cukup baik, karena pihak madrasah memiliki tahapan-tahapan yang ideal dengan menggunakan prinsip-prinsip manajemen yaitu pelaksanaan, pengorganisasian, pelaksanaan dan evaluasi; kedua, implementasi dengan menggunakan bauran pemasaran di MA Miftahurroja Lebakmuncang Ciwidey cukup berhasil dan efektif, karena dengan produk, promosi, tempat, harga, orang, sarana dan prasarana, dan proses yang dimiliki pihak madrasah bisa meningkatkan jumlah animo pendaftar peserta didik disetiap tahunnya. Sehingga MA Miftahurroja Lebakmuncang Ciwidey masih tetap eksis di dunia pendidikan dan menjadi alternatif orang.

\section{Daftar Pustaka}

Abrori, Maskub, Strategi Pemasaran Dan Implementasinya Dalam Lembaga Pendidikan, 2nd edn (Bandung: Alfabeta, 2013)

—, 'Strategi Pemasaran Lembaga Pendidikan Untuk Meningkatkan Jumlah Peserta Didik Di PG/TK Samarinda', SYAMIL: Jurnal Pendidikan Agama Islam (Journal of Islamic Education), 3 (2015)

Anam, Khoirul, 'Strategi Pemasaran Dan Implementasinya Dalam Lembaga Pendidikan', Ta'allum: Jurnal Pendidikan Islam, 1 (2013), 159-70.

Arikunto, Suharsini, Prosedur Penelitian Suatu Pendekatan Praktek (Jakarta: Rineka Cipta, 2003)

Buckley, Philip, and Irawan Irawan, 'The Scientific Paradigm of Islamic Education Management: Phenomenology Perspective', Jurnal Pendidikan Islam, 02 (2015), 1-29.

Fahmi, I, Manajemen Strategis, 1st edn (Bandung: Alfabeta, 2015)

Faizin, Imam, 'Strategi Pemasaran Jasa Pendidikan Dalam Meningkatkan Nilai Jual Madrasah', Madaniyah, 7 (2017)

Dirasah, Vol. 3, No. 1, Februari 2020 
Jaswita, Derizka Inva, 'Strategi Pemasaran Jasa Pendidikan Dalam Meningkatkan Volume Penerimaan Siswa Baru SD Kartini Komplek Angkasa Pura II', Jurnal Pemasaran Kompetitif, 2 (2018) .

KBBI, Kamus Besar Bahasa Indonesia (KBBI), 4th edn (Jakarta: Balai Pustaka, 2005)

Khasanah, Afidatun, 'Pemasaran Jasa Pendidikan Sebagai Strategi Peningkatan Mutu Di SD Alam Baturraden’, El Tarbawi, 8 (2015), 161-76.

Lexy J. Moleong, Metode Penelitian Kualitatif (Bandung: Remaja Rosdakarya, 2004)

Muhaimin, Manajemen Pendidikan, Aplikasinya Dalam Penyusunan Rencana Pengembangan Sekolah/Madrasah, 4th edn (Jakarta: Kencana Preneda Media Group, 2012)

Prayoga, Ari, and Jaja Jahari, 'Manajemen Jejaring Kerjasama Pondok Pesantren', AL MA'ARIEF : Jurnal Pendidikan Sosial Dan Budaya, 01 (2019), 125-33.

Prayoga, Ari, and Arif Risnandi, 'Manajemen Pembiayaan Pendidikan Di Madrasah Aliyah Darussalam Sumedang', Cakrawala: Jurnal Manajemen Pendidikan Islam Dan Studi Sosial, 03 (2019), 117-31 .

Prayoga, Ari, Azhar Widad, Elin Marliana, Ima Mukarromah, and Uus Ruswandi, 'Implementasi Penjaminan Mutu Madrasah', Muróbbî: Jurnal Ilmu Pendidikan, 3 (2019), 70-84 .

Tim Dosen Administrasi Pendidikan UPI, Manajemen Pendidikan, Alfabeta, 1st edn (Bandung: Alfabeta, 2011)

Wakil Kepala Bidang Kurikulum, 'Dokumen 1 Madrasah Aliyah Miftahurroja Lebakmuncang Ciwidey' (Bandung: MA Miftahurroja, 2019)

—, 'Dokumen Rencana Strategi Madrasah Aliyah Miftahurroja Lebakmuncang Ciwidey’ (Bandung: MAS Miftahurroja, 2019)

Zaenal, Uus, 'Wawancara Bersama Kepala Madrasah MAS Miftahurroja' (Bandung: Researcher, 2019) 
Copyright @ 2020 Journal Dirasah: Vol. 3, No. 1, Februari 2020, p-ISSN: 2615-0212, e-ISSN; 2621-2838

Copyright rests with the authors

Copyright of Jurnal Dirasah is the property of Jurnal Dirasah and its content may not be copied or emailed to multiple sites or posted to a listserv without the copyright holder's express written permission. However, users may print, download, or email articles for individual use.

https://ejournal.iaifa.ac.id/index.php/dirasah

Dirasah, Vol. 3, No. 1, Februari 2020 